\title{
Morpho-agronomic characterization and analysis of genetic divergence among accessions of tomatoes (Solanum lycopersicum L.)
}

\author{
Murilo de Oliveira Fernandes ${ }^{1 *}$ Paola Alvares Bianchi ${ }^{2}$ (ígia Renata Almeida da Silva ${ }^{2} \odot$ \\ Larissa Souza Vianna ${ }^{2} \odot$ Eileen Azevedo Santos $^{2} \odot$ Monique Moreira Moulin $^{3} \odot$
}

${ }^{1}$ Universidade Federal do Rio Grande (FURG), 96203-900, Rio Grande, RS, Brasil. E-mail: murilo fernan@hotmail.com. "Corresponding author. ${ }^{2}$ Universidade Estadual do Norte Fluminense Darcy Ribeiro (UENF), Campos dos Goytacazes, RJ, Brasil. ${ }^{3}$ Instituto Federal do Espírito Santo (IFES), Alegre, ES, Brasil.

ABSTRACT: The collection and characterization of tomato germplasm are of relevant importance for agriculture. This study aimed to collect and characterize, by way of morphological description and statistical tools for the composition of groups, tomato accesses from the Southern and Serrana regions of the State of Espirito Santo, as well as to establish the tomato germplasm bank of the Ifes - Campus de Alegre. Thirtyseven accessions were collected from different commercial locations of Espirito Santo. The experiment was conducted in the Ifes Campus de Alegre in the Agroecology sector. For the morpho-agronomic characterization, sixteen essential descriptors were used, nine quantitative and seven qualitative. In the color of the ripe fruit, there was the formation of five distinct groups with the colors yellow, green, orange, pink and red. In the format of the fruit, three groups were formed, slightly flattened, flattened and rounded. The ANOVA showed that there was a significant difference for all the quantitative characteristics evaluated. According to the Ward-MLM procedure, due to the high likelihood function in group seven (from 130.71), it was possible to group the 37 genotypes into seven groups. The greatest dissimilarity was observed in groups $V$ and VII with a distance of 330.02, and the least dissimilar ones, groups IV and VI, with 8.21. Genetic variability was detected in tomato germplasm for the morpho-agronomic characteristics. Many of the accessions are promising sources of phenotypes of interest to the Ifes germplasm bank. Key words: germplasm, genetic diversity, qualitative and quantitative characters.

Caracterização morfo-agronômica e análise da diversidade genética entre acessos de tomates (Solanum lycopersicum L.)

RESUMO: A coleta e caracterização do germoplasma de tomate são de relevante importância para a agricultura. O presente trabalho objetivou coletar e caracterizar, por intermédio de descritores morfoagronômicos e ferramentas estatísticas, os acessos de tomate das regiões Sul e Serrana do Estado do Espírito Santo, bem como constituir o banco de germoplasma de tomate do Ifes, Campus de Alegre. Foram coletados 37 acessos de tomate em diferentes pontos comerciais do Espírito Santo. O experimento foi conduzido no Setor de Olericultura do Ifes Campus de Alegre. Para a caracterização morfoagronômica, foram utilizados 16 descritores essenciais, 9 quantitativos e 7 qualitativos. Para a característica cor do fruto maduro, houve a formação de cinco distintos grupos com as cores amarelo, verde, laranja, rosa e vermelha. No formato do fruto, houve formação de três grupos, ligeiramente achatado, achatado e arredondados. A ANOVA mostrou que houve diferença significativa para todas as características quantitativas avaliadas. Pelo procedimento Ward-MLM, devido a elevada função de verossimilhança no grupo sete (de 130.71), foi possivel agrupar os 37 genótipos em sete grupos. A maior dissimilaridade foi observada nos grupos V e VII com distância de 330.02, e os menos dissimilares, os grupos IV e VI, com 8.21. Detectou-se variabilidade genética no germoplasma de tomate para as características morfoagronômicas. Muitos dos acessos são promissoras fontes de fenótipos de interesse para o banco de germoplasma do Ifes.

Palavras-chave: Germoplasma, diversidade genética, caracteres qualitativos e quantitativos.

\section{INTRODUCTION}

Cultivated tomatoes (Solanum lycopersicum L.) originated in South America, more precisely in the Andean region, comprising Chile, Bolivia, Peru, Ecuador and Colombia (WARNOCK, 1991; MINAMI, 1980). The species belongs to the Solanaceous family, being first denominated Solanum esculentum Mill, but reclassified and organized as the species Solanum lycopersicum L. (PERALTA et al., 2006).
As it is cultivated in tropical and subtropical regions around the world, the fruit can be used for fresh consumption and for industrialization, standing out as the second most cultivated horticultural crop in the world, being surpassed only by potato (FAO, 2016).

Tomato is one of the most important crops in the world, being considered one of the most lucrative, and serving catering to different markets (MACIEL et al., 2016). The tomato cultivated in Brazil is basically derived from genetic material from 
Europe and the United States, with the exception of some discovered wild materials relatives (CARELLI et al., 2006). The production of tomatoes has shown a significant increase over the years (IBGE, 2016), becoming one of the most widespread in the world; for obtaining great yields in extremely short cycles, and being a horticultural crop of great commercial importance. Among these crops, it is one of the most important, not only for its economic value but also for maintaining family farming (WAMSER et al., 2015). Tomato presents variability in morphological characteristics of leaves, flowers, fruits, agronomic traits, and others. For genetic diversity studies, an analysis of morpho-agronomic characteristics is important. The characterization of tomato accessions is fundamental for recognition and use of genotypes (MARIM et al., 2009).

The tomato's genotype information has been stored in germplasm banks, that are fundamental for genetic improvement, contributing to the increase of productivity and agricultural sustainability (PRECZENHAK et al., 2014), with the interest of representing genetic variability and staring at different species.

The characterization has been carried out in germplasm collections to generate description and classification information of conserved material. Genetic divergence, based on morpho-agronomic characters, has been widely used by researchers to identify potential crosses for obtaining segregating populations with high variability (MORILLO et al., 2015).

Germplasm banks are fundamentally important, because they provide researchers with an ample source of genetic resources, and can also provide the most diverse types of genes that confer adaptation to different abiotic stresses as well as resistance to numerous pests and diseases (GONÇALVES et al., 2008).

In this context, the present study had the objective of collecting and characterizing, by means of morpho-agronomic descriptors, tomato accessions from the Southern and Serrana regions of the State of Espírito Santo, accessions from Minas Gerais as a comparative standard and establishing after that the tomato's germplasm bank with the purpose of providing subsidies for future studies.

\section{MATERIALS AND METHODS}

The tomato accessions hailed from municipalities in the Southern and Serrana regions of the State of Espírito Santo and two accessions from Minas Gerais, as a comparative standard. They were collected through visits to rural properties and supermarkets. In commercial establishments, twentythree accessions were collected: eight in GuaçuíES, two in Venda Nova do Imigrante-ES, eight in Cachoeiro de Itapemirim-ES, two in Castelo-ES, one in Alegre-ES and two in Durandé-MG. In the rural properties, fourteen accessions were collected; all from Venda Nova do Imigrante-ES, totaling thirtyseven accessions. A minimum amount of three fruits/tomato samples per accessions was collected. Collecting was carried out from May to June 2014.

The experiment was initially conducted in the Ifes Campus de Alegre's agroecology sector for seedling formation, in greenhouse conditions. Seeds were placed in pairs, in trays with 200 cells. At 20 days, after the seedlings developed four leaves, they were planted in field conditions at the Ifes Campus de Alegre's Olericulture sector, in soil prepared with organic fertilizer. The planting period and gathering of accessions was between July and September of the year 2014.

The experimental design was completely randomized with thirty-seven treatments (accessions) with six replicates, totaling 222 plants (Figure 1). The spacing was $1.0 \mathrm{~m}$ between the rows and $0.5 \mathrm{~m}$ between the plants. The tomato plants were cultivated under field conditions, with treated soil, and after 90 days of planting morphological characterization were performed. All the crop maintenance used with tomato accessions is in accordance with the ones recommended by FILGUEIRA (2005).

Accessions were characterized by highly specific discriminant morpho-agronomic tomato descriptors, which are available from Bioversity International (Descriptors for Tomato - IPGRI, 1996). Nine quantitative characteristics were evaluated: plant height (AP), crown diameter (DC), number of loci (NL), number of seeds (NS), diameter (DFr) and fruit length $(\mathrm{CFr})$, diameter of the stem (DCa), length (CFo) and leaf diameter (DFo); and seven qualitative characteristics: fruit color at the mature stage (CFrm), fruit color at the immature stage (Fri), fruit shape (FF), growth habit (HC), leaf shape (FFol), leaf density DFol) and leaf color (CFol).

Quantitative descriptors were submitted to the normality test of the data by the Lilliefors method. After checking the assumptions for a variance analysis, the characters were submitted to test. Analysis of variance was conducted according to a completely randomized design with the aid of the GENES program (CRUZ, 2013).

Quantitative variables were analyzed using the Ward-MLM procedure for the composition of 


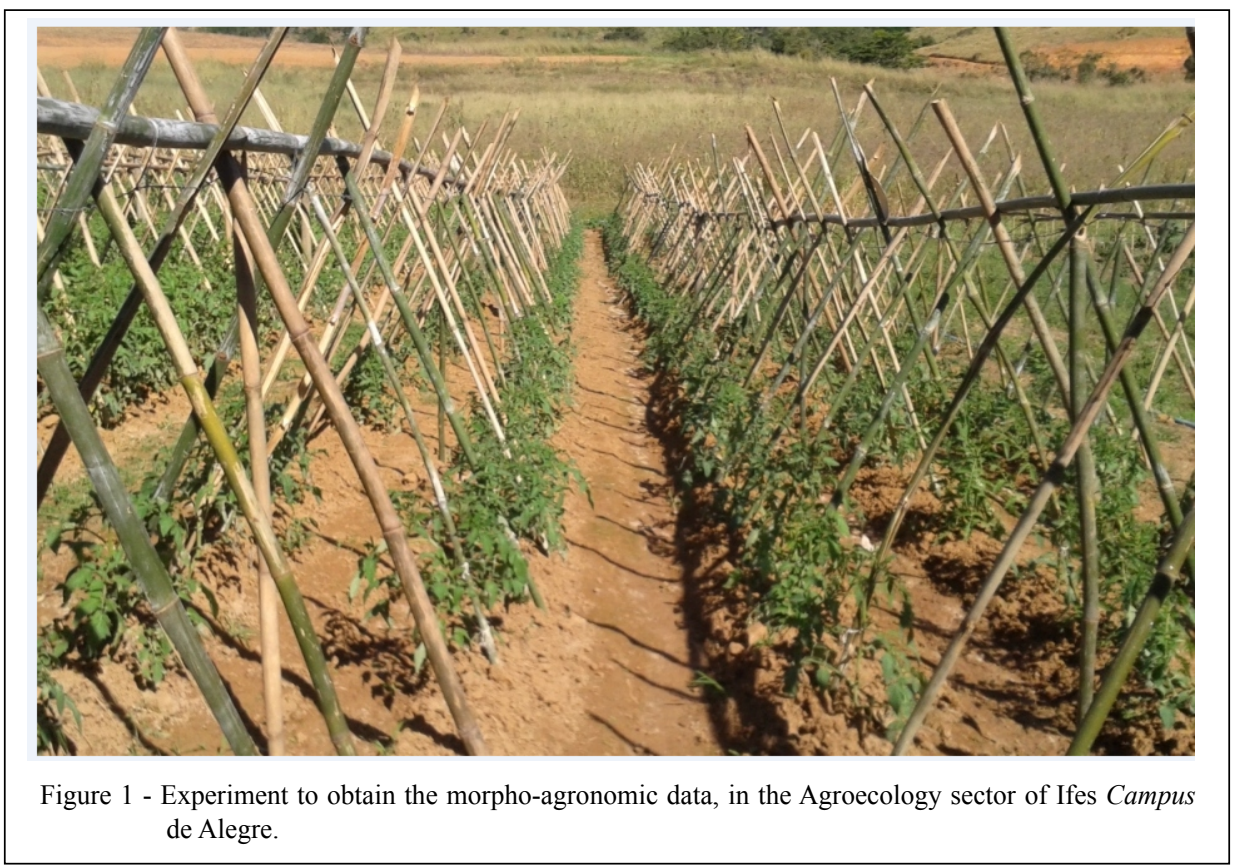

the genotype groups, using the CLUSTER and IML procedure of the SAS program (SAS Institute, 2000). For the application of the Ward grouping method, the distance matrix was obtained by the Gower algorithm (GOWER, 1971). The definition of the ideal number of groups was performed according to the pseudo-F and pseudo-t 2 criteria combined with the likelihood profile associated with the likelihood ratio test (SAS Institute, 2000).

\section{RESULTS AND DISCUSSION}

Qualitative characteristics presented different results in the variation composition in relation to color and fruit format. The CFrim descriptor was monomorphic, that is, $100 \%$ of the genotypes presented a greenish-white color (Figure 2). The green color for immature fruits is attributed to chlorophyll. However, it is important to note that, to improve fruit quality, it is necessary to evaluate the effect of chlorophyll on fruit growth (RINALDI et al., 2013). A different result was observed by VARGAS et al. (2015) verified in the access 'Rosa', white when immature and pink when mature. The fruit color characteristic is quite variable between both immature and mature genotypes.

For the CFrm characteristic, there was a color variation in fruit ripening, resulting in the formation of five groups. Group 1, with $51.31 \%$ of the

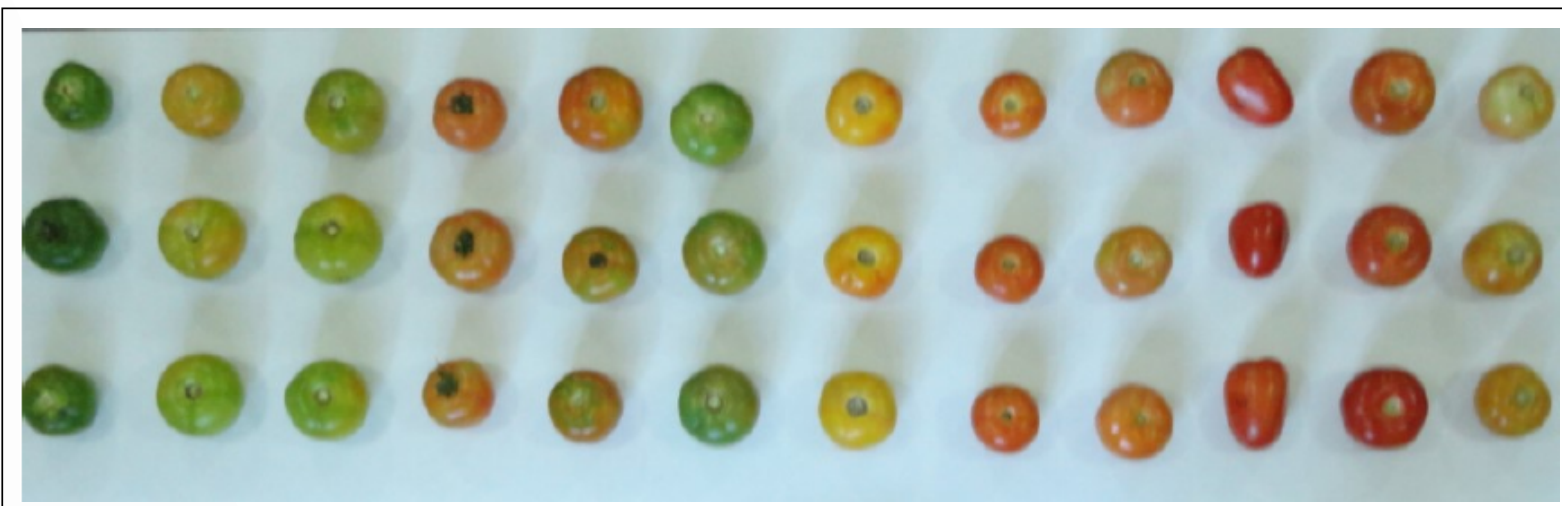

Figure 2 - Diversity of colors and formats found among the 37 accessions of S. lycopersicum L.

Ciência Rural, v.48, n.11, 2018. 
yellow genotypes, the second with $32.43 \%$ green, the third with $8.11 \%$ orange, the fourth with $5.41 \%$ pink and the fifth with only $2.7 \%$ of the fruits of red color. For tomato, this event is common, similar results were identified in other research such as de ROCHA et al. (2010), who observed the predominance of red color in ripe fruits, but also reported yellow, orange and brown fruits in cherry tomatoes.

VARGAS et al. (2015) evaluating the genetic diversity in accessions of heirloom tomatoes, in addition to the red color, was highlighted for fruits of intense yellow, pink-orange, and intense pink. The variation of color can indicate an attractive in the consumer market because it adds more beauty to culinary dishes. AGUDELO et al. (2011) characterizing cherry tomatoes, reported in mature fruits the formation of three groups, $47.82 \%$ red, $43.47 \%$ pink and $4.34 \%$ yellow.

The coloration of tomato fruit is indicative of substances called carotenoids. These are natural substances present in plants (and other organisms, such as algae, bacteria) that give fruits and plants the yellow, orange and red colorations. The types of carotenoids most reported in the tomato composition are lycopene and $\beta$-carotene (SAINI et al., 2015). In addition to pigmentation, these substances have anti-cancer and immunomodulatory effects, aiding in the prevention of cancer and cardiovascular diseases (MAYNE, 1996).

FF is also a characteristic that, in studies of characterization and diversity tend to be very variable. In this study, the difference in this characteristic formed three groups: $75.68 \%$ of the genotypes presented a slightly flattened shape, $16.22 \%$ flattened fruits and 8.11\% rounded. ROCHA et al. (2010) verified a greater variation in five groups: globular, cordiform, cylindrical, periform and slightly flattened fruits. VARGAS et al. (2015) also reported a great variation for tomato fruits. AGUDELO et al (2011) showed that $36.84 \%$ with round shape, $26.31 \%$ slightly flat, $21.05 \%$ cylindrical shape and $15.7 \%$ round elongated.

The form of the fruits in tomato is a characteristic that results from the action of varied gene loci, with different functions. Therefore, the study of the FF inheritance is very important for the breeding of the species (MACIEL \& SILVA, 2008).

Regarding the habit of plant growth, all accessions showed indeterminate growth. According to KRIEGER et al. (2010), the monitoring of the production for industry generally uses plants of indeterminate growth, due to their reduced size and greater uniformity of maturation, facilitating the mechanized harvest for industrial processing. All accessions presented leaf deltoid format. According to IPNI (2014), the commercial tomato leaf has this characteristic. NASS (2007) reports that cultivated tomatoes have predominantly the deltoid form.

In the density and leaf color descriptors, it was observed that $99.42 \%$ of the plants had intermediate density and green coloration. The color of the leaf can represent the quality of the fruit and if the plant is receiving the necessary nutrients, adequate sunlight and is free of any pest or disease. SILVA et al. (2013) emphasized that leaf color is determined by the expression of a gene with incomplete dominance and has high heritability and; therefore, the leaves are generally green. The analysis of variance showed that there were significant differences for all the quantitative characteristics evaluated, and for NL, NS, DFr, CFr, DCp, DCa, LFo and DFo the differences were highly significant $(\mathrm{p} \leq 0.01)$ and only AP was significant at 5\% (Table 1).

In relation to the coefficient of variation (CV), a discrepancy between the characteristics was observed (Table 1). According to the classification of PIMENTEL GOMES (1985), CVs less than or equal to $10 \%$, such as those reported for DFr, CFr and DFo, have a low dispersion of the variables. Between 10 and $20 \%$, observed for NS, DCp, DCa, LFo, a mean dispersion. From 20 to $30 \%$, in NL and AP, as high dispersion of the data. No values above $30 \%$ were observed, which shows a high dispersion of the variables.

The lower $\mathrm{VCs}$ are related to the uniformity in the characteristic values, thus, the fruits are similar because they presented the lowest variations in the CFr and DFr, as well as in the DFo (Table 1). ROCHA et al. (2010) evaluating cherry tomato fruits, also presented low variations for both characteristics (CFr and DFr). AGUDELO et al (2011) found, with cherry tomato characterization, greater variability for the characteristics of $\mathrm{CFr}$ and DFr, among the quantitative characteristics evaluated. According to TANKSLEY (2004), fruits originating from domesticated species are often significantly higher than those normally reported in wild-type progenitor species.

The DFo is a characteristic that associated to the leaf length make possible to estimate the leaf area. Being a measurable measure, the tendency is for the $\mathrm{CV}$ to be high. The low variation of this characteristic in this research is attributed to the specificity of each evaluated genotype and not to failures in the evaluation. RODRIGUES et al. (2008) characterizing 25 cherry tomato genotypes, also observed differences $(\mathrm{p} \leq 0.01)$ for DFo and a CV of $9.8 \%$. 
Table 1 - Analysis of variance for nine quantitative characteristics of 37 accessions of Solanum lycopersicum L.

\begin{tabular}{|c|c|c|c|c|c|c|}
\hline FV & GL & $\mathrm{QM} N L^{*}$ & \multicolumn{2}{|c|}{ QMNS } & $\mathrm{QM} D F r$ & $\mathrm{QM} C F r$ \\
\hline Trat & 36 & $8.47^{* *}$ & \multicolumn{2}{|c|}{$8962.25^{* *}$} & $786.27^{* *}$ & $299.81^{* *}$ \\
\hline Error & 74 & 0.76 & \multicolumn{2}{|c|}{871.92} & 17.13 & 10.26 \\
\hline Average & & 3.72 & \multicolumn{2}{|c|}{148.23} & 65.96 & 58.59 \\
\hline CV (\%) & & 23.46 & \multicolumn{2}{|c|}{19.92} & 6.27 & 5.46 \\
\hline FV & GL & $\mathrm{QM} A P$ & $\mathrm{QM} D C p$ & $\mathrm{QM} D C a$ & $\mathrm{QM} L F_{O}$ & $\mathrm{QM} D F_{O}$ \\
\hline Trat & 36 & $0.28^{*}$ & $0.10^{* *}$ & $0.57^{* *}$ & $88.44^{* *}$ & $114.30^{* *}$ \\
\hline Error & 74 & 0.15 & 0.04 & 0.47 & 4.11 & 4.69 \\
\hline Average & & 1.51 & 1.31 & 4.61 & 19.82 & 28.55 \\
\hline CV (\%) & & 26.1 & 16.61 & 14.96 & 10,23 & 7.58 \\
\hline
\end{tabular}

*: NL-n ${ }^{\circ}$ of locules. NS-n ${ }^{\circ}$ of seeds, DFr -fruit diameter, CFr -length of fruit, AP -plant height, DCp -cup diameter, DCa -stem diameter, LFo - sheet width and DFo -leaf diameter.

The high CV for the characteristics of NL and $\mathrm{AP}$ is attributed to the great variability reported in genotypes evaluated in tomato genotypes, especially when dealing with genotypes from different collection locations. MARINS et al. (2009) evaluated the genetic variability in tomato accessions, also observed a high variation in NL in the fruits, between 2 and 10NL per fruit. CORTÉS-OLMOS et al. (2015) evaluating local varieties of Spain, showed that the characteristic that most oscillated was NL. ROCHA et al (2010) also observed high variation in NL in cherry tomato fruits. $\mathrm{NL}$ is associated with the number of carpels and is related to the shape of the fruit. Commercially, fruits with three or four NL are the preferences for the consumed besides being associated with the greater mass of the fruit (BLAT et al., 2007).

Evaluating the AP, BENETTI et al. (2018), observed that the larger the spacing, the greater the development capacity both in relation to height and fruit production. This feature is susceptible to variation because it is sensitive to several factors such as spacing and irrigation slides (SOARES et al., 2011; MULLER and WAMSER, 2009). CRUZ \& REGAZZI (2012) point out that genetic variability in plant size can serve as the main indicator for choosing a genetic matrix. In general, tall tomato plants are more productive, while dwarf-sized plants are of interest to the ornamental market.

The Ward-MLM procedure was used to distinguish the 37 genotypes. According to the pseudo-F and pseudo-t2 criteria, seven groups were established. This is due to the increase in the likelihood function observed in group seven, that is, 130.71 (Figure 3). In this way, the method guaranteed a more precise definition, resulting in less subjective groupings of the genotypes. This Ward-MLM strategy has been applied to several crops, such as banana (PEREIRA et al., 2012), guava (CAMPOS et al., 2013) and passion fruit (SANTOS, 2013).

Differently, GONÇALVES et al. (2009) evaluating tomato accesses of the germplasm bank through 22 descriptors using the Ward-MLM strategy, verified the formation of five groups with variability within the groups. SUDRÉ et al. (2010) evaluating 56 accessions of Capsicum from the germplasm bank of the Northern Fluminense State University Darcy Ribeiro (UENF), determined the ideal number of groups at five. KUROSAWA et al. (2017) evaluating popcorn corn genotypes, determined four as the optimal number of groups by the WardMLM strategy. This number may differ according to species, the number of accessions and number and type of descriptors (GONÇALVES et al., 2009).

The Ward-MLM classification strategy for the analysis of morpho-agronomic data allowed the separation of the 37 genotypes into seven homogeneous groups, grouped according to their similarities. Group I consisted of 14 genotypes; group II, by five genotypes; group III, by four genotypes, group IIII, by four genotypes, group V by five genotypes, group VI by three genotypes and group VII by two genotypes. The clear separation between the groups indicatedthat the morpho-agronomic characters were efficient to discriminate the 37 genotypes.

Group I allocated accesses that presented median values for the majority of the evaluated characteristics and greater heterogeneity regarding the collection site, grouping accesses representatives 


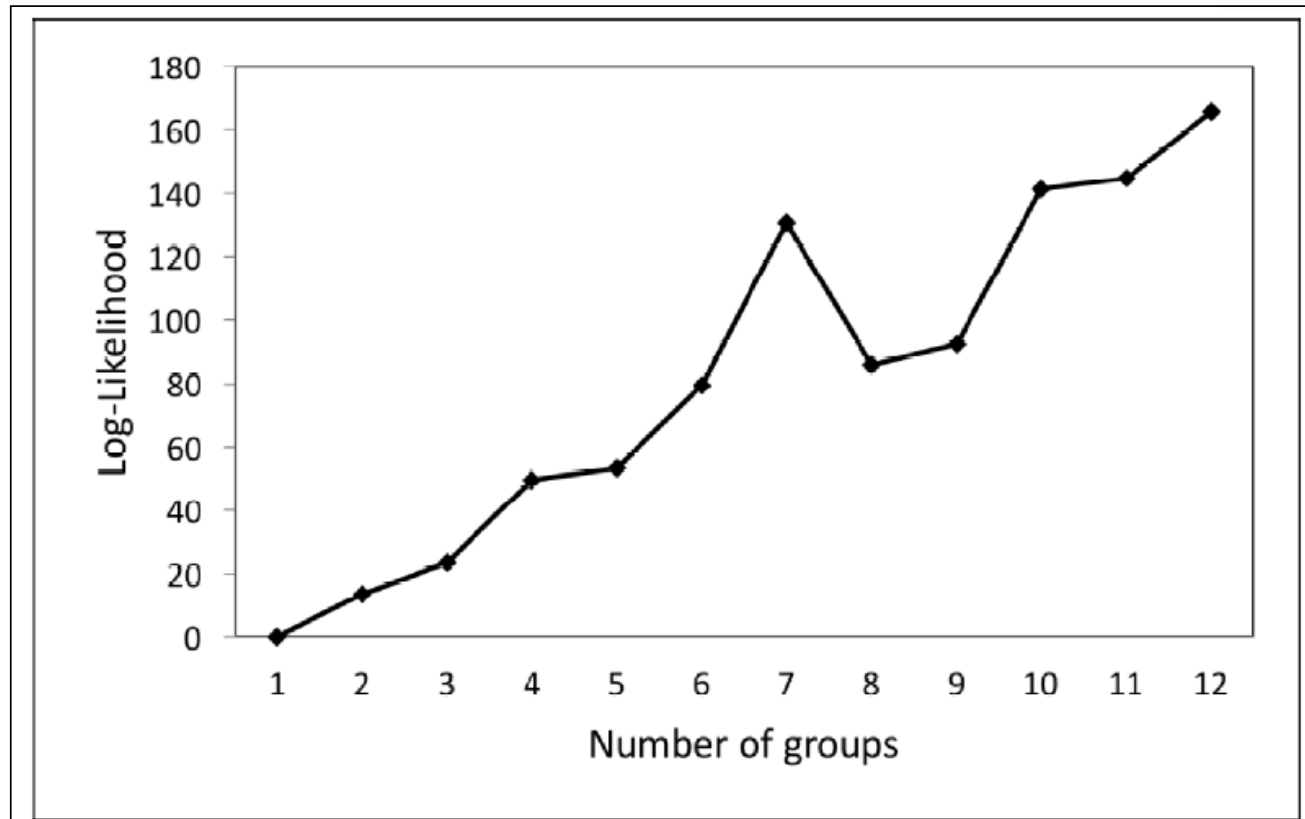

Figure 3 - Graph of log-likelihood in relation to the number of groups formed by the Ward MLM strategy in $S$. lycopersicum L.

of all the localities, due to the intense exchange of seeds among small producers. In agreement with this study, other studies also observed this non-association (RÊGO et al., 2011; MOULIN et al., 2012; BIANCHI et al., 2016). Group II had accesses that presented the highest averages for leaf length and width.

Accessions with higher plant height and crown diameter were allocated in group III. SOLINO et al. (2010) stated that the high growth of a cultivar can be very important for purposes of post-harvest vegetable cover since it provides an increase in yield. In this sense, these variables are directly related to growth and biomass production. The growth of a tomato plant is evaluated by the product between the height and the diameter of the crown (MAROUELLI et al., 2015).

Groups IV and V collected accesses that presented the lowest and highest mean for fruit length, respectively. Large fruits make access quite attractive for consumers who want to produce sauces (VARGAS et al., 2015). Diversity of sizes in tomato fruit is a characteristic of interest, since even the majority of the fruits commercialized in natura are of the types Santa Cruz and Salada, the types Cherry and Italian have been gaining space in the commerce of this herbarium, presenting culinary versatility, being indicated for in natura consumption or in raw salads (SABIO et al., 1997).
The highest averages for stem diameter were pooled in group VI. According to LÚCIO et al. (2012), a larger stem diameter may be related to the species' own characteristics and even the influence of the meteorological conditions. MUELLER and WAMSER (2009) aiming to verify the relationship between planting spacing and shoot height of tomato plants to obtain high productivity and fruit quality, observed that plants with higher average values of stem diameter presented a reduction in plant height, according to the same authors, such characteristics are considered inversely proportional, corroborating with the present study.

Group VII grouped the accesses with the highest number of loci, number of seeds and diameter of fruit. VARGAS et al., (2015) studying 22 tomatoes accessions presented variation from 2 to 11 locules. ALVARENGA (2004) points out that the number of locules is directly proportional to the number of seeds present. MATTEDI et al. (2007), when conducting research with numerous commercial varieties, reported, on average, the number of the locus for commercial tomatoes varies between 3 and 5 per fruit. The first two canonical variables (VC) obtained using the Ward-MLM methodology explained $81.76 \%$ of the total variation (Figure 4).

Ciência Rural, v.48, n.11, 2018. 


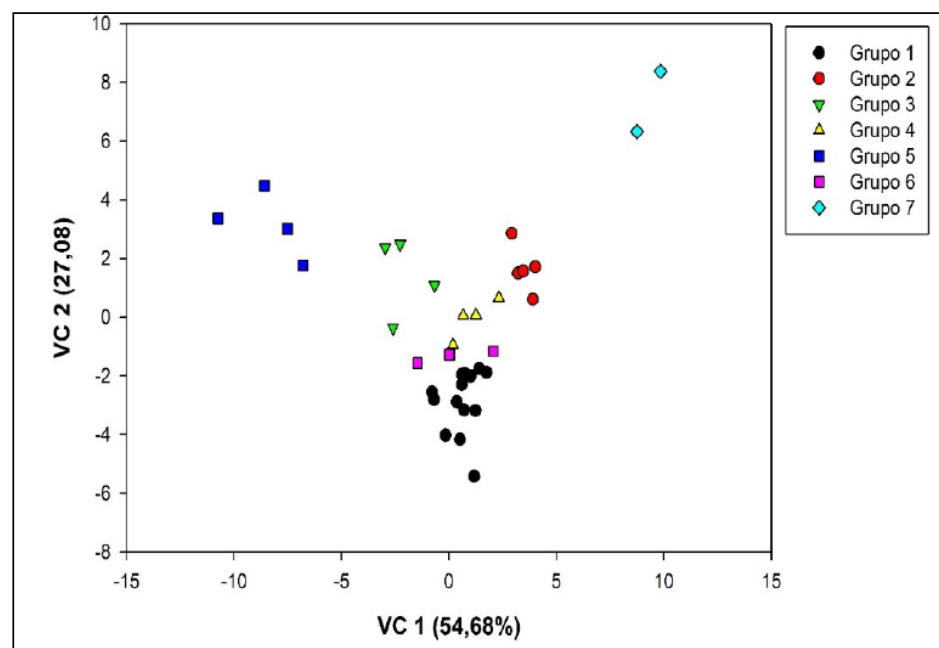

Figure 4 - Chart of the first two canonical variables for the seven groups formed by the Ward-MLM analysis in S. lycopersicum L.

This high value indicates that a twodimensional chart is adequate to visualize the relationship between the groups and between the genotypes within the groups. The number of seeds and number of loci with 0.77 and 0.70 , respectively (Table 2), were the main contributors to genetic divergence, based on the first canonical variable.

By means of the graphical analysis of the VC, greater dissimilarity was obtained between groups V and VII (Figure 3), with a distance of 330.02 , such divergence can be explained due to the discrepancy between the variables number of loci,

Table 2 - Averages of the quantitative variables for each of the seven groups formed by the Ward-MLM method and the two canonical variables, in S. lycopersium L.

\begin{tabular}{|c|c|c|c|c|c|c|c|c|c|}
\hline \multirow{2}{*}{ Descrit $^{1}$} & \multicolumn{7}{|c|}{ 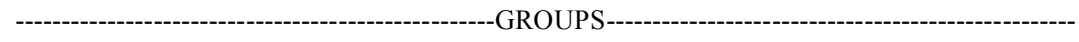 } & \multicolumn{2}{|c|}{----------CAN---------- } \\
\hline & GI (14) & GII (5) & GIII (4) & GIV (4) & GV (5) & GVI (3) & GVII (2) & CAN I & CAN II \\
\hline Nloc & 3.45 & 4.3 & 2.55 & 3.9 & 2.5 & 3.5 & 9.15 & 0.70 & 0.42 \\
\hline Nsem & 163.71 & 214.85 & 75.74 & 111.91 & 89.46 & 138.88 & 251.83 & 0.77 & 0.03 \\
\hline Diamfr & 72.71 & 76.2 & 34.28 & 59.02 & 54.18 & 73.53 & 88.39 & 0.59 & -0.15 \\
\hline Cfru & 57.83 & 62.33 & 49.15 & 44.13 & 73.09 & 57.85 & 67.22 & -0.20 & 0.34 \\
\hline Altpl & 1.58 & 1.34 & 1.69 & 1.62 & 1.52 & 1.4 & 0.95 & -0.34 & -0.37 \\
\hline Dcop & 1.36 & 1.26 & 1.51 & 1.34 & 1.19 & 1.14 & 1.17 & 0.01 & -0.26 \\
\hline Dca & 4.6 & 4.68 & 4.23 & 4.81 & 4.33 & 4.91 & 4.89 & 0.38 & -0.02 \\
\hline Lfol & 18.51 & 27.63 & 14.79 & 19.33 & 21.94 & 20.97 & 13.93 & -0.03 & 0.05 \\
\hline Cfol & 27.76 & 36.36 & 28.14 & 24.82 & 30.55 & 27.16 & 21.18 & -0.11 & 0.03 \\
\hline
\end{tabular}

${ }^{1}$ Nloc -Number of locules; Nsem -Number of seeds; Diamfr -Diameter of fruit; Cfru -Length of fruit; Altpl -Plant Height; Dcop -Crown diameter; Dca -Stem diameter; Lfol -Width of sheet; Cfol -Sheet length.

Ciência Rural, v.48, n.11, 2018. 
seeds, and diameter of the between the two groups. In contrast, the less dissimilar groups were grouped IV and VI, with a distance of 8.21, such groups presented very close values for almost all the evaluated characteristics (Table 2).

\section{CONCLUSIONS}

The characterization and identification of these accessions allow their use as progenitors in future strategies used in breeding programs of the species. Genetic variability was detected in tomato germplasm for the morpho-agronomic characteristics. Many of the accesses are promising sources of phenotypes of interest to the IFES germplasm bank.

\section{DECLARATION OF CONFLICTING INTERESTS}

The authors declared no potential conflicts of interest with respect to the research, authorship, and/or publication of this article.

\section{AUTHORS' CONTRIBUTIONS}

All authors contributed equally for the conception and writing of the manuscript. All authors critically revised the manuscript and approved of the final version.

\section{REFERENCES}

AGUDELO, A.G.A. et al. Caracterización morfológica del tomate tipo cereza (Solanum lycopersicum L.), agron. 19(2): 44 - 53, 2011

ALVARENGA, M.A.R. Tomate: produção em campo, em casade-vegetação e em hidroponia. Lavras: UFLA, 2004. p.37-60.

BENETTI, R. et al. Densidade de plantio e substâncias húmicas no cultivo do tomateiro (Solanum lycopersicum L). Revista de Agricultura Neotropical, Cassilândia-MS, v. 5, n. 1, p. 75-81, Jan./Mar, 2018. ISSN 2358-6303.

BIANCHI, P.A. et al. Morphological characterization and analysis of genetic variability among pepper accessions. Ciência Rural. v.46, n.7, p.1151-1157, 2016.

BLAT, S.F. et al. Avaliação de híbridos duplos de pimentão. Horticultura Brasileira, 25: 350-354, 2007.

CAMPOS, B. M. et al. Quantificação da divergência genética entre acessos de goibeira por meio da estratégia Ward-MLM. Revista Brasileira de Fruticultura, 35(2), 87-94, 2013.

CARELLI, B.P. Genetic diversity among Brazilian cultivars and landraces of tomato Lycopersicon esculentum Mill. Revealed by RAPD markers. Genetic Resources and Crop Evolution 53: 395400, 2006.

CORTÉS-OLMOS, C. et al. Traditional Eastern Spanish varieties of tomato. Scientia Agricola, n.5, p.420-431, September/October, 2015.
Available from: $<$ http://dx.doi.org/10.1590/0103-9016-2014-0322>. CRUZ, C.D. et al. Modelos biométricos aplicados ao melhoramento genético. v. 1, 4. ed. Viçosa: UFV, 2012, 514 p.

CRUZ, C.D. GENES - a software package for analysis in experimental statistics and quantitative genetics. Acta Scientiarum, 35(3):271-276, 2013.

FAO-FAOSTAT. Database Results. Available from: $<$ http://apps. fao.org . 2016>.

FILGUEIRA, F.A.R. Novo manual de olericultura: agrotecnologia moderna na produção e comercialização de hortaliças. Viçosa: UFV, 2012. 402p.

GONÇALVES, L.S.A. et al. Divergência genética em tomate estimada por marcadores RAPD em comparação com descritores multicategóricos. Horticultura Brasileira, v. 26, p. 364-370, 2008.

GONÇALVES, L.S.A. et al. Heirloom tomato gene bank: assessing genetic divergence based on morphological, agronomic and molecular data using a Ward-modified location model. Genetics and molecular research, v.8, n.1, p.364-374, 2009.

GONÇALVES, G.M. et al. Genetic parameter estimates in yellow passion fruit based on design I. Brazilian Archives of Biology and Technology, 52:523- 530, 2009.

GOWER J.C. A general coefficient of similarity and some of its properties. Biometrics. 27: 857-874, 1971.

IBGE-Instituto Brasileiro de Geografia e Estatística. Produção Agrícola Municipal (PAM), Rio de Janeiro. Available from: $<$ http://www.sidra.ibge.gov.br>. 2016.

KUROSAWA, R.N.F. et al. Multivariate approach in popcorn genotypes using the Ward-MLM strategy: morphoagronomic analysis and incidence of Fusarium spp. Genetics and Molecular Research v.16, n.1, 2017. gmr16019528. doi: 10.4238/gmr16019528.

LÚCIO, A.D. et al. Tamanhos de amostra e de parcela para variáveis de crescimento e produtivas de tomateiro. Horticultura Brasileira, Brasília, v. 30, p. 660-668. 2012.

IPNI. The International Plant Names Index. IPNI. Disponível em: www.ipni.org, 2014.

KRIEGER, $U$. The flowering gene single flower truss drives heterosis for yield in tomato. Nature Genetics, v.42, p.459-463. 2010.

MACIEL, G. M. et al. Agronomic potential of mini tomato hybrids with determinate and indeterminate growth habit. Horticultura Brasileira, 34(1), 144-148. 2016.

MACIEL, G.M., SILVA, E.C. Herança do formato do fruto em tomateiro do grupo cereja. Horticultura Brasileira, 26: 495498, 2008.

MARIM, B.G. et al. Variabilidade genética e importância relativa de caracteres em acessos de germoplasma de tomateiro. Pesquisa Agropecuária Brasileira, v.44, p.12831290, 2009.

MAROUELLI, W.A. et al. Frações ótimas da adubação com fósforo no préplantio e na fertirrigação por gotejamento de tomateiro. Pesq. agropec. bras., Brasília, v.50, n.10, p.949-957, out. 2015. doi: 10.1590/S0100-204X2015001000011. 
MATTEDI, et al. Tomate: tecnologia de produção. Viçosa: UFV. 2007.

MAYNE, S. T. Beta-carotene, carotenoids, and disease prevention in humans. FASEB Journal, 10: 690-701, 1996.

MINAMI, K. O tomateiro. Campinas, Fundação Cargill, 2. ed., $1980,310 \mathrm{p}$.

MORILLO, S.R.C., SILVA, G.S.D. Antagonistic effect of jack bean on Meloidogyne enterolobiiin tomato plants. Summa Phytopathologica, 41(4), 305-310. 2015.

MOULIN, M.M. et al. Collection and morphological characterization of sweet potato landraces in north of Rio de Janeiro state. Horticultura Brasileira, v.30, n.2, p.40-51, 2012.

MUELLER, S. WAMSER, A. F. Combinação da altura de desponte e do espaçamento entre plantas de tomate. Horticultura Brasileira, Brasília, DF, v. 27, n. 1, p. 64-69, Jan./Mar. 2009.

PERALTA, I.E. et al. Nomenclature for wild and cultivated tomatoes. Feature article. Rep Tomato Genet Coop, 56:6-12, 2006.

PEREIRA, V.M. et al. Genetic diversity between improved banana diploids using canonical variables and the Ward MLM method. Pesquisa Agropecuária Brasileira, 47(10):1480-1488, 2012.

PIMENTEL GOMES, F. Curso de Estatística Experimental. São Paulo: Nobel, 467 p., 1985.

PRECZENHAK, A. P. et al. Caracterização agronômica de genótipos de mini-tomate. Horticultura Brasileira, 32(3), 348-356. 2014.

RÊGO, E.R. et al. Morphological and chemical characterization of fruits of Capsicum spp. accessions. Horticultura Brasileira, v.29, n.2, p.364-371, 2011.

ROCHA, M.C., et al. Uso do algoritmo de Gower na determinação da divergência genética entre acessos de tomateiro do grupo cereja. Maringá, 2010. v. 32, n. 3, p. 423-43.

RODRIGUES, M.B. et al. Caracterização morfológica de 25 cultivares de tomateiro tipo cereja - caracteres da plantal. Horticultura Brasileira 26: S4461-S4467, 2008.
SABIO, R. P. et al. Mini e "baby" frutas e Hortaliças. Revista Hortifruti Brasil, Piracicaba, n. 120, p. 8, São Paulo: IEA/ SAA, 1997.

SAINI, R.K. et al. Carotenoids from fruits and vegetables: Chemistry, analysis, occurrence, bioavailability and biological activities. Food Research International, v. 76, n. August, p. 735$750,2015$.

SANTOS, E.A. Melhoramento do maracujazeiro-azedo (Passiflora edulis sims) visando à resistência ao cowpea aphidborne mosaic virus. 2013. Tese de Doutorado - UENF.

SILVA, C.A. et al. Herança da cor de folhagens em hortaliças. VII Simpósio de Pesquisas do Brasil, 2013.

SOARES, L.A.A. et al. Taxa de crescimento do tomateiro sob lâminas de irrigação em ambiente protegido. Revista Verde, v.6, n. 2 , p. 210,2011

SOLINO, A.J.S. et al. Cultivo orgânico de rúcula em plantio direto sob diferentes tipos de coberturas e doses de composto. Revista Caatinga, 23: 18-24. 2010.

SUDRÉ, C.P. et al. Genetic variability in domesticated Capsicum spp as assessed by morphological and agronomic data in mixed statistical analysis. Genetic and Molecular Research 9:283294, 2010.

TANKSLEY, S.D. The genetic, developmental, and molecular basis of fruit size and shape variation in tomato. The plant cell 16 : S181-S189. 2004

VARGAS, T.O. et al. Diversidade genética em acessos de tomateiro heirloom. Horticultura Brasileira 33: 174-180, 2015. doi: 10.1590/S0102-053620150000200007.

WAMSER, A. P. et al A. Análise de correspondência múltipla para caracterização de produtores rurais por práticas agrícolas: tomaticultura em Caçador, Brasil. Revista de Ciencias Agroveterinárias, 14 (1), 75-83. 2015.

WARNOCK, S. J. Natural habitats of Lycopersicon species. HortSciense, v.26, n. 5, p. 466-471, 1991 